\title{
Integrative Learning Model Based on History and Local Culture in High Schools
}

\author{
Umasih $^{1}$, Budiaman ${ }^{2}$, M. Fakhruddin ${ }^{3}$, Firdaus Hadi Santosa ${ }^{4}$ \\ \{umasih@unj.ac.id ${ }^{1}$, budiaman@unj.ac.id², fakhruddin@unj.ac.id ${ }^{3}$, firdaushadi@unj.ac.id $\left.{ }^{4}\right\}$ \\ ${ }^{1,3,4}$ Historical Education Study Program, Faculty of Social Sciences, Universitas Negeri Jakarta, \\ Indonesia \\ ${ }^{2}$ Social Sciences Education Study Program, Faculty of Social Sciences, Universitas Negeri Jakarta, \\ Indonesia
}

\begin{abstract}
It is necessary to design an integrative learning model based on history and local culture to provide an understanding of history and local culture for senior high school students. The aim is for students to have knowledge and insight about the history and local culture in their surrounding neighborhoods. The introduction of local history and culture is essential for students to be understood well that their history and local culture also need to be studied and preserved as part of Indonesia's cultural richness. The study in this article is only a preliminary study that will produce an integrative model of history and local culture-based learning for high school students in the Bogor and Banten region, which have a wealth of historical and local cultural sites that can be regulated through curricular and extracurricular activities.
\end{abstract}

Keywords: integrative learning model, history and local culture

\section{Introduction}

Learning history awakens students as historical creatures. Creatures that have limitations, as well as freedom, are always held accountable. A historical being means that humans are agents and make history. What humans have is not their nature, but their history. That proves that historical awareness does not occur naturally. There are structural, cultural and horizontal barriers that cause many people to not realize themselves as historical actors. For this reason, history learning becomes very urgent, even fundamental in building humanity dimensions. History is not only colored by physical evidence but also the dimensions of values and thought. Through reflection, contemplation and thinking about humans in their life struggles with events in the past, it allows humans to capture the meaning of life.

History is not only understood as a series of events, but also the meaning behind that historical event. Therefore, if you want to know the meaning of history it will be related to the question of where humans come from and where they are going. This includes various factors that enable humans and their cultures to continue to exist and develop, even though other communities are of course in a static position and may even be extinct. For this reason, learning based on history and local culture needs to be developed intact, creative and critical in the frame of humanity so that students understand their locality.

Many attempts have been made to criticize historical learning in the context of national interests. Efforts to reconstruct the glory in the past to explain the present must be used as 
inspiration in the fight for Indonesia's bright and hopeful future. However, learning based on history and local culture for high school students has not been done much. One of the contributing factors is because in the 2013 Curriculum especially the subject of Indonesian History which is currently in force does not explicitly include the Basic Competencies regarding local historical and cultural material.

Whereas the awareness of the community's condition of the history and local culture around the immediate environment of students who have become part of the national struggle must be introduced by giving opportunities and independence of thinking to high school students as the young generation of heirs and successors to the nation. It is hoped that by providing an integrative learning model based on history and local culture, the process of forming the identity of the Indonesian nation can be well understood.

The problem of integrative learning based on history and local culture with its various dimensions becomes very complex at the theoretical and implementation levels. The constellation between integrative learning models based on history and local culture with efforts to strengthen national identity becomes very relevant. Several high schools in Bogor and Banten are close to the surrounding historic and cultural sites. For this reason, the constellation of research problems becomes very strategic. Respect for cultural differences because it is thus socially easier to accept culture widely. When viewed from the Indonesian people, Bhinneka Tunggal Ika is a philosophy about diversity. The Indonesian people have a long history of unity and diversity, even Indonesia was built on this diversity.

Diversity through a multicultural education model in the Religion-Based High School in anticipating the symptoms of national disintegration. The results indicate that multicultural education developed on the diverse historical and local cultural backgrounds of Indonesia strongly supports the process of understanding the diversity and integration of the nation. This learning model based on culture and local history is one of the real efforts in increasing students' understanding of history and culture in their locality. This is based on the concept that the learning model is a conceptual framework that contains systematic procedures and organizes student learning experiences to achieve certain goals that serve as guidelines for teachers in teaching and learning [1]. So the learning model in question is a learning model that refers to local cultural and historical values. The learning model based on culture and local history is the answer to be able to raise awareness of multicultural Indonesian nationality. Because history learning is one of the means of forming character and national awareness [2], [3]. Besides it is also important for the development of students' thinking abilities and learning abilities [4].

The importance of developing a culture-based learning model and local history is one of them to build multicultural awareness, as the research "Multicultural Education in Local History Learning" concluded that learning through local history is important to build multicultural education related to values typical of the local history of each region [5]. Besides, through local history-based learning makes students aware of historical relics in their environment, which also affects the change in students' views on history, and the nation's historical value [6]. Local history and culture have many benefits in learning at school because it can enrich and complement existing learning history so that it can be juxtaposed with national and world history [7]. Both culture and local history also have an important portion in shaping character or fostering national character values. This is because both local culture and history have special values that differ between regions so that a culture-based learning model and local history can provide a more tangible experience for students because it is related to the noble values that develop in society.

The research conducted by Supardi discusses multicultural education in the learning of 
local history, which focuses on multicultural education. While Oguzhan's research discusses the learning of local history by using social learning models. Actekin's research is more on the position of local history in learning history. Which discusses the development of learning based on local cultural values. Although these studies are equally concerned with local history and culture, they use a different approach. Several studies related to learning local history and learning based on cultural values, both suggested that learning based on culture and local history had benefits in student development.

Although these studies differ in method and research perspective, the results together reinforce the information that local culture and history are important for further study. The results of this study intend to explore aspects of the studies that have not been disclosed, namely learning models based on culture and local history. This research contributes to filling these gaps so that it is expected to develop a learning model that can increase students' understanding of certain local cultural and historical backgrounds.

This is importantly related to efforts to preserve local culture and history, especially in Bogor and Banten. Indonesian society that is diverse certainly has its local culture and history which is also very diverse, so this model of learning based on culture and local history is one of the real efforts in increasing students' understanding of history and culture in their locality. The learning model based on culture and local history is the answer to be able to raise awareness of multicultural Indonesian nationality.

\section{Research methods}

This research method uses research and development or research and development. This research and development has ten stages of activities: (1) potential and problems (2) data collection (3) product design (4) product validation (5) product revision (6) product trial (7) product revision (8) test try the product (9) product revision (10) mass production (Sugiyono, 2015). Schematically can see in the following figure: the main text should be written using Times New Roman, 10pt, fully justified. Italics can be used for emphasis and bold typeset should be avoided.

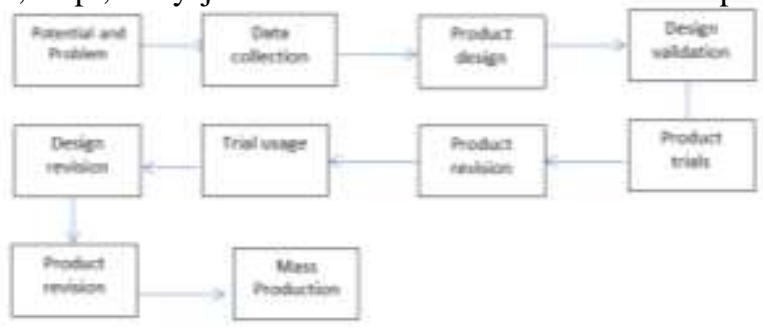

Fig.1. Product development stages

\section{Results and discussion}

Hellomotion High School is one of the schools in South Tangerang, Banten Province, explaining that an integrative learning model based on local culture and history is usually done 
outside of school. The teacher first learns Basic Competencies as listed in the history curriculum then synchronizes them with local cultural study material at the same time and students are introduced to field trip activities. Field trip activities can be done twice, field trips are carried out around the school while large field trips are carried out in a wider environment while introducing the culture and local wisdom of the people of Tangerang.

Pandeglang High School has identified several figures and sites that students must know by integrating them into learning history. The figures such as K H. Syam'un, Banten sultanate, KyaiWasid, GegerCilegon, Menadana Menes, Slate Site, Citaman Site, Cidanghiyang Site, Old Banten Mosque, and Temple. The general material inserted was ordered and discussed by students related to local history. To learn more about history and children are more interested. At least introduce history that is closest to the lives of students.

In Pandeglang High School, an effort was made to integrate history and local culture by introducing the history of Multatuli figures and cultural traditions of the Baduy people, because not many students were familiar with the Baduy Culture let alone visit it. The goal is that students know the history and culture in their area. The Baduy community is a native of Banten, West Java. They live in the foothills of the Kendengmountains, Kenkes Village, Lauwidamar District, Lebak Regency, Banten. Baduy is a designation given by the outside community and originated as a researcher. Researchers equate them with nomadic or nomadic groups of people. Historically the word "Baduy" was given by the government of the sultanate of Banten when the indigenous Banten people were reluctant to accept the teachings of Islam, they were finally exiled to the interior. This material is usually inserted in an explanation of the Islamic Kingdom in Banten.

According to one of the history teachers who is also the head of the MGMP History of Banten Province, in Banten, there is a Governor Regulation No. 15/2014 related to integrated local content of art and culture which consists of rump drum, Batik, and Pencak Silat. Other cultures that need to be introduced: (1) reading and writing skills of Banten pigeon letters, and (2) introducing Banten Folklore. To realize this regulation there are several attempts made (1) holding a Banten History course with the Banten historian resource, (2) held a workshop on the preparation of integrated History RPP Banten History, (3) arrange teaching materials and learning media Banten Local History in the form of motion graphics (still draft), and (4) technically insert a GPA and Banten local history material in accordance with BC 6.

Why is this done? The goal of gar history is closer to daily life and can understand the immediate environment: family history, society, the area itself. Besides, pre-literate life in Banten was also provided. History of Banten sultanate, colonialism, and imperialism in Banten, the resistance of Europeans in Banten, struggle to maintain independence in the Banten region, as well as introducing figures of freedom fighters from Banten. In YPBH Bogor High School the teacher explained that local wisdom in Bogor City was connected with the history of Sundanese or Pajajaran. Explained about Bogor Tempo Doeloe, Culture and others.

The history of the classical period, the process of cultural and religious change in Bogor, and the influence of European, Chinese and Arabic culture on Bogor society. The principle that is taken into consideration by integrating history and local culture into the study of History is where the earth stands where the sky is held. As Bogor people and living or settling in Bogor, students should know the history and culture in Bogor. Both in the classical, megalithic, European Hindu-Buddhist, and Japanese colonization. Even though there are obstacles that are faced, namely the source is difficult to find as concrete evidence that can be shown to students, but they are interested, enthusiastic, and their curiosity is quite high about the culture of local wisdom in Bogor, for example, Pajajaran with various stories. 


\section{Conclusion}

Historical and cultural differences that are owned by Indonesian people are used as Indonesian wealth that needs to be passed on to young generations such as high school students in the Bogor and Banten regions. Both of these regions have a history and are rich in the local culture which also needs to be understood by students from both regions. On the basis of a study of research at Tangerang Hellomotion High School, 4 Pandeglang High School, 6 Pandeglang High School, 1 Ciruas High School and YPBH Bogor High School it can be concluded that integrative learning of history and local culture is important not only to enrich students' insights into the history and culture of their region but more than that to strengthen its identity as part of the Indonesian community and nation. Indonesia has a variety of wealth following the supporting community.

The five schools though come from different regions namely Bogor and Banten. the teachers are well aware of the importance of introducing local history and culture that is around the student's residence. The teacher and student informants agreed that the integrative learning model of local history and culture could be applied to schools in Indonesia especially those in Bogor and Banten. Learning by integrating local history and culture is important to strengthen the identity of students as part of the Indonesian community and citizens.

\section{References}

[1] N. Wedyawati, "Pengaruh Model Pembelajaran IPA Terintegrasi Mitigasi Bencana terhadap Hasil Belajar.," Edukasi J. Pendidikan., vol. 15, no. 2, pp. 261-273, 2017.

[2] Sardiman, "Pembelajaran Sejarah Dan Pembangunan Karakter Bangsa," in Pendidikan Sejarah Untuk Manusia Dan Kemanusiaan: Refleksi Perjalanan Karir Akademik Prof. DR. Said Hamid Hasan, MA, H. Kamarga, Ed. Jakarta: Bee Media Indonesia, 2012.

[3] S. K. Kochar, Pembelajaran Sejarah: Teaching of History. Jakarta: PT. Grasindo, 2008.

[4] H. Hasan, "The Development of Historical Thinking and Skills in the Teaching of History in the Senior Secondary School Curriculum in Indonesia," Hist. Internatioal J. Hist. Educ., vol. XI, no. 2, 2010.

[5] Supardi, "Pendidikan Multikultural dalam Pembelajaran Sejarah Lokal," J. Pembang. Pendidik. Fondasi dan Apl., vol. 2, no. 1, 2014.

[6] K. Oguzhan, "Teaching Local History Using Social Studies Models for Turkish Middle School Students.," Educ. Res. Rev., vol. 10, no. 8, pp. 1284-1292, 2015.

[7] S. Aktekin, "The Place and Importance of Local History in the Secondary History Education," J. Theory Pract. Educ., vol. 6, no. 1, 2010. 